\title{
ADVOKASI HAK-HAK PEREMPUAN ASISTEN RUMAH TANGGA OLEH LEMBAGA BANTUAN HUKUM ASOSIASI PEREMPUAN UNTUK KEADILAN (LBH APIK) JAKARTA
}

\author{
Ayu Sopia Yudistika \\ UIN Syarif Hidayatullah Jakarta \\ Email: ayusopia56@gmail.com
}

Received: 9th August 2018; Revised: 12th October 2018; Accepted: 15th December 2018

\begin{abstract}
A household assistant (Asisten Rumah Tangga-ART) is a profession oftenly underestimated, especially females who are prone to violence, intimidation, discrimination and neglect of their rights as workers. Thus, ART needs a protection. This research conducted to comprehend how regulation related to women household assistants. As well as how to advocate their rights carried out by Legal Aid Body such as LBH APIK Jakarta. This research uses a descriptive qualitative that is describing certain situations based on data obtained in the field related to the rights of women household assistants. The data collection technique is by a field research with interviews of three lawyers and one internal coordinator, documentation study at LBH APIK Jakarta, and library research. The results of this study show that advocacy by LBH APIK Jakarta related to the rights of Household Assistants have two models of protections. One is case management and policy advocacy through the formulation of Household Assistant Law, which is still being prioritized and advocated to date.
\end{abstract}

Keywords: Advocacy, Household Assistant, LBH Apik Jakarta, Women's Rights.

Abstrak. Asisten rumah tangga merupakan suatu pekerjaan yang sering dipandang sebelah mata, terutama ART perempuan yang memang rentan sekali mengalami tindak kekerasan, intimidasi, diskriminasi dan juga penelantaran hak-haknya sebagai pekerja. Dengan demikian perempuan ART membutuhkan perlindungan. Hal tersebut menjadi latar belakang mengapa penelitian ini dilakukan, yaitu untuk mengetahui bagaimana regulasi terkait dengan perempuan asisten rumah tangga. Serta bagaimana advokasi hakhak perempuan asisten rumah tangga yang dilakukan oleh LBH APIK Jakarta. Penelitian ini menggunakan metode kualitatif yang bersifat deskriptif yaitu menggambarkan situasi tertentu berdasarkan data yang diperoleh di lapangan secara terperinci terkait dengan hak-hak perempuan asisten rumah tangga. Teknik pengumpulan data yang dilakukan penulis adalah penelitian lapangan dengan melakukan wawancara kepada tiga orang pengacara dan satu orang koordinator internal, dokumentasi di LBH APIK Jakarta, serta penelitian kepustakaan. Adapun hasil penilitian ini juga menunjukan bahwa advokasi yang dilakukan LBH APIKJakarta terkait hak-hak perempuan Asisten Rumah Tangga yang memiliki dua model dalam melakukan perlindungan terhadap hak-hak perempuan ART yaitu dengan cara penanganan kasus dan juga berupaya untuk memberikan perlindungan khusus terhadap ART dalam bentuk Undang-undang PRT yang masih di prioritaskan dan diadvokasikan sampai saat ini.

Kata Kunci: Advokasi, Asisten Rumah Tangga, LBH Apik Jakarta, Women's Rights 


\section{Advokasi Hak-hak Perempuan Asisten Rumah Tangga oleh Lembaga Bantuan Hukum Asosiasi Perempuan untuk Keadilan (LBH APIK) Jakarta}

- Ayu Sopia Yudistika

\section{Pendahuluan}

Pekerja asisten rumah tangga (ART) menjadi salah satu pilihan pekerjaan yang diminati oleh sebagian besar perempuan Indonesia dari berbagai latar belakang pendidikan. Hal tersebut dilakukan untuk membantu memenuhi kebutuhan keluarga di tengah sulit mendapatkan pekerjaan yang layak. Kemungkinan mereka bekerja mencari nafkah untuk membantu perekonomian keluarga, untuk mencukupi kebutuhan sehari-hari yang dirasa tingkat kebutuhan yang meningkat dan sangat besar (Wiludjeng, 2005). Tingkat ekonomi maupun tingkat pendidikan yang umumnya rendah, membuat kaum perempuan sulit untuk bekerja di sektor formal. Pilihan yang memberikan kemudahan bagi mereka yaitu masuk pada pekerjaan informal (Wiludjeng, 2005). Maka dari itu di Indonesia khususnya, pekerjaan yang sangat mudah dilakukan oleh perempuan yang tingkat ekonomi dan tingkat pendidikannya rendah, biasanya memilih sebagai asisten rumah tangga.

Menurut estimasi global dan regional mengenai pekerja rumah tangga yang dibuat oleh Program Kondisi Kerja dan Pekerjaan (Internasional Labour Office, 2016), setidaknya 52,6 juta perempuan dan laki-laki berusia diatas 15 tahun menjadi asisten rumah tangga sebagai pekerjaan utama mereka pada tahun 2010. Angka ini merepresentasikan porsi signifikan pekerjaan berupah secara global, sekitar 3,6 persen di seluruh dunia. Perempuan membentuk mayoritas besar asisten rumah tangga 43,6 juta atau 83 persen dari jumlah total. Pekerjaan sebagai asisten rumah tangga merupakan sumber penting pekerjaan berupah bagi perempuan, sekitar 7,5 persen pekerja perempuan di seluruh dunia. Hingga 2.593.000 asisten rumah tangga diperkirakan bekerja di Indonesia, sekitar 75\% ART di Indonesia adalah perempuan dan sebagian besar berasal dari kawasan pedesaan dan umumnya berpendidikan rendah, dari jumlah ini 1,4 juta asisten rumah tangga diperkirakan bekerja di Jawa saja.

Semakin banyaknya masyarakat Indonesia yang menggunakan jasa asisten rumah tangga untuk membantu pekerjaan rumah tangga, maka semakin banyak kemungkinan asisten rumah tangga mengalami kekerasan maupun penelantaran hak-haknya. Salah satu penelitian yang dilakukan oleh Muslihati Nurhidayati pada tahun 2011, yang membahas bahwa bahwa asisten rumah tangga perempuan memerlukan perlindungan hukum yang khusus untuk melindungi asisten rumah tangga dari tindak kekerasan, intimidasi, eksploitasi maupun penelantran hak-haknya sebagai pekerja (Hidayati, 2016). 
Adapun regulasi yang dapat digunakan dalam melindungi ART perempuan, seperti penelitian yang dilakukan oleh Sri Turatmiyah dan Annalisa Y pada tahun 2013, bahwa perlindungan hukum terhadap perempuan sebagai asisten rumah tangga secara tegas diatur dalam hukum internasional mendasar mengenai perlindungan perempuan dari segala bentuk diskriminasi yaitu Konvensi mengenai Penghapusan Segala Bentuk Diskriminasi terhadap Wanita (Convention on the Elimination of All Form of Discrimination against Women/ CEDAW). Selain dari pada itu perlindungan hukum bagi perempuan asisten rumah tangga dapat juga ditemukan dalam Undang-Undang No. 23 tahun 2004 Tentang Penghapusan Kekerasan Dalam Rumah Tangga (KDRT) pasal 5 yang menerangkan bahwa kekerasan dalam rumah tangga bisa terjadi salah satu bentuknya adalah adanya penelantaran dalam rumah tangga, termasuk pekerja rumah tangga (Turatmiyah \& Y, 2013). Dan juga undang-undang tersebut memberikan hak-hak bagi korban, bahwa korban berhak mendapatkan perlindungan dari pihak keluarga, kepolisian, kejaksaan, pengadilan, advokat, pelayanan kesehatan, lembaga sosial atau pihak lainnya.

Terkait dengan perlindungan terhadap hak-hak perempuan asisten rumah tangga. Maka advokasi adalah bentuk pertolongan terhadap asisten rumah tangga perempuan yang rentan mengalami kekerasan maupun penelantaran hak- haknya. Selain dari pada itu, dibutuhkan lembaga bantuan hukum untuk melindungi perempuan asisten rumah tangga dari tindak kekerasan maupun penelantaran hak-haknya. Salah satunya yaitu Lembaga Bantuan Hukum Asosiasi Perempuan Indonesia untuk Keadilan (LBH APIK ) Jakarta yang memberikan bantuan hukum dengan berspektif gender (perempuan) kepada setiap masyarakat khususnya bagi kaum perempuan yang tidak mampu untuk mendapatkan keadilan dan juga perlindungan. Upaya yang dilakukan LBH APIK Jakarta dalam memberikan perlindungan terhadap perempuan asisten rumah tangga adalah dengan cara melakukan advokasi atau pendampingan baik itu di luar maupun di dalam pengadilan oleh seorang advokat (pengacara) dan juga LBH APIK Jakarta menjadi bagian dari jaringan advokasi untuk memeperjuangkan lahirnya Rancangan Undang-Undang Perlindungan PRT, agar asisten rumah tangga menjadi sebuah profesi yang memperoleh penghargaan dari masyarakat maupun pemerintah. Seperti yang dijelaskan (Dalrymple dan Boylan, 2016), bahwa Terdapat dua model untuk mengidentifikasi dua unsur advokasi, yaitu: a) Kasus atau advokasi berbasis masalah (dimana pekerjaan difokuskan dengan 


\section{Advokasi Hak-hak Perempuan Asisten Rumah Tangga oleh Lembaga Bantuan Hukum Asosiasi Perempuan untuk Keadilan (LBH APIK) Jakarta}

- Ayu Sopia Yudistika

individu atau kelompok kecil seperti keluarga dengan cara tugas berpusat); dan b) Sistemik atau menyebabkan advokasi (dimana pengetahuan dari kasus- kasus individu memberikan kontribusi untuk advokasi bersama untuk perubahan sistemik undang-undang, kebijakan atau praktik)

Berdasarkan penjelasan diatas terlihat bahwa begitu pentingnya advokasi yang dilakukan LBH APIK Jakarta terhadap pemenuhan hak-hak perempuan asisten rumah tangga baik berupa penanganan kasus maupun upaya pembentukan regulasi terhadap asisten rumah tangga yang berbentuk Undang- undang PRT yang masih terus di prioritaskan. Hal ini diharapkan dapat membantu ART perempuan dalam memperjuangkan hak-haknya sebagai pekerja, baik berupa bantuan hukum ataupun dalam bentuk regulasi khusus untuk melindungi ART perempuan dari tindak kekerasan, intimidasi, diskriminasi ataupun penelantaran hak-haknya sebagai pekerja. Hal ini sejalan dengan penelitian yang dilakukan oleh (Mansyur, 2009), dijelaskan bahwa pentingnya suatu Lembaga dalam memberikan perlindungan terhadap asisten rumah tanggaterutamaasisten rumah tangga perempuanyang rentan mengalami tindak kekerasan fisik, psikis dan juga ekonomi. Penelitian tersebut dilakukan di LSM Rumpun Tjoet Njak Dien (Yogyakarta) terkait dengan penanganan terhadap PRT perempuan yang mengalami tindak kekerasa dalam rumah tangga. LSM ini memperjuangkan hak-hak PRT khususnya pekerja perempuan, bertujuan untuk membebaskan nasib PRT dari berbagai keterbelakangan dan nasib buruk yang kadang itu semua muncul dari arogansi dan egoisme para majikan. Ada pun advokasi yang dilakukan oleh LSM tersebut yaitu dengan melakukan kampanye perlindungan PRT.

Atas dasar tersebut, peneliti tertarik untuk melakukan penelitian ini karena peneliti melihat bahwa asisten rumah tangga masih membutuhkan perlindunganterkait dengan hak-haknya perempuan asisten rumah tangga. Salah satunya dengan cara melakukan advokasi baik terhadap klien maupun terhadap sistem atau kebijakan. Hal tersebut dapat ditemukan dalam suatu lembaga yaitu, Lembaga Bantuan Hukum APIK yang merupakan suatu lembaga pertama di Indonesia yang memberikan perlindungan terhadap perempuan yang membutuhkan keadilan. LBH APIK Jakarta menjadi lembaga pertama dalam melakukan advokasi berspektif gender (perempuan) baik itu dalam advokasi klien maupun advokasi sistem atau kebijakan, hal ini dapat terlihat dari struktur organisasi LBH APIK yang memiliki dua devisi yaitu devisi 
pelayanan hukum dan juga devisi perubahan hukum, dimana devisi pelayanan hukum memberikan bantuan hukum kepada semua perempuan Indonesia yang membutuhkan keadilan dengan cara pendampingan baik di dalam maupun di luar pengadilan. Selain itu devisi perubahan hukum di LBH APIK berperan aktif untuk terus mengkampanyekan ataupun memprioritaskan segala bentuk perlindungan terhadap perempuan yang membutuhkan keadilan dengan cara membuat undang-undang baru salah satunya Undang-undang perlindungan PRT yang sampai saat ini masih terus di optimalkan dan di prioritaskan.

\section{Metode}

Metode pendekatan yang digunakan penulisan skripsi ini adalah pendekatan penelitian kualitatif yaitu metode penelitian yang bertujuan untuk memecahkan masalah-masalah kehidupan praktis (Sugiyono, 2010). Metode kualitatif juga memiliki pengertian sebagai prosedur penelitian yang menghasilkan data deskriptif berupa kata-kata yang tertulis atau lisan dari orangorang perilaku yang diamati (Bogdan dan Taylor 2007). Adapun penelitian ini bersifat deskriftif (Descriptive Research), yaitu penelitian yang menggambarkan atau melukiskan situasi tertentu berdasarkan data yang diperoleh di lapangan secara terperinci sesuai dengan fokus penelitian yang telah ditetapkan (Maelong, 2007). Penulis menggunakan metode kualitatif deskriptif yaitu bertujuan untuk menggambarkan dan menjelaskan secara teori dan praktik berdasarkan data yang diperoleh di lapangan secara terperinci yaitu terkait dengan regulasi hakhak asisten rumah tangga serta advokasi yang dilakukan oleh LBH APIK Jakarta dalam memenuhi hak-hak Asisten Rumah Tangga.

Dalam melakukan penelitian ini, peneliti ditunjang oleh data primer dan data sekunder. Data primer adalah data asli yang dikumpulkan oleh peneliti (Sunyoto, 2013). Data primer pada penelitian ini bersumber dari wawancara dan observasi. Dalam hal ini peneliti memperoleh hasil wawancara dari pengacara LBH APIK Jakarta dan Koordinator Internal LBH APIK Jakarta. Sedangkan data sekunder adalah data yang diperoleh dengan cara melakukan studi dokumentasi. Data sekunder ini merupakan data yang diperoleh dari data literature kepustakaan seperti buku-buku, karya tulis berupa makalah, koran, atau lainnya yang bisa menunjang informasi yang dibutuhkan peneliti. 


\section{Advokasi Hak-hak Perempuan Asisten Rumah Tangga oleh Lembaga Bantuan Hukum Asosiasi Perempuan untuk Keadilan (LBH APIK) Jakarta}

- Ayu Sopia Yudistika

\section{Hasil dan Diskusi}

\section{Regulasi Terkait dengan Perempuan ART}

Regulasi di Indonesia diartikan sebagai sumber hukum formil berupa peraturan perundang-undangan yang memiliki beberapa unsur yaitu suatu keputusan yang tertulis, dibentuk oleh lembaga Negara atau pejabat yang berwenang dan mengikat umum (Indriati, 2007). Regulation memiliki pengertian aturan atau ketertiban yang dipaksakan melalui ketentuan hukum yang ditetapkan oleh pemerintah melalui wewenang eksekutif (Pujileksono, 2016). Regulasi atau aturan yang digunakan dalam melakukan perlindungan hukum bagi ART maka perlunya payung hukum berupa undang-undang PRT.

Dari penelitian yang dilakukan oleh Sri Turatmiyah dan Annalisa Y bahwa, banyaknya pelanggaran terhadap hak-hak ART telah menjadi salah satu faktor pendorong lahirnya kesadaran perlunya sebuah aturan yang komprehensif tentang Asisten Rumah Tangga yang dapat melindungi hak-hak mereka. Salah satunya Rancangan Undang-Undang Perlindungan Pekerja Rumah Tangga yang masuk menjadi salah satu prioritas dalam Program Legislasi Nasional (Prolegnas) tahun 2010 hanya saja sampai saat ini belum terealisasikan menjadi Undang-undang PRT (Turatmiyah \& Y, 2013). Hal tersebut diperjelas kembali oleh Ibu Siti Lestari, pengacara LBH APIK bahwa kurang lebih sepuluh tahun LBH APIK Jakarta melakukan advokasi terhadap undang-undang PRT, hanya saja sampai saat ini undang-undang PRT masih belum menjadi prioritas di tingkat DPR. Maka masih banyak pertimbangan serta banyak hal yang masih perlu disempurnakan terkait undang-undang PRT tersebut.

Upaya yang dilakukan untuk menyempurnakan dan juga agar undangundang PRT tersebut menjadi prioritas dalam pembahasan di DPR, maka LBH APIK terus berusaha melakukan revisi-revisi serta diskusi maupun dialog bersama agar terbentuk suatu undang-undang PRT tersebut. Namun masih banyak pertimbangan dalam merealisasikan Undang-undang PRT tersebut.

Dalam hal ini salah satu bahan pertimbangana kenapa belum terealisasinya Undang-Undang PRT adalah karena perlakuan ART yang terkadang juga dapat merugikan majikannya. Hal ini terjadi karena belum adanya kesatuan pendapat untuk mendorong terbentuknya Undang-undang PRT ini. Seperti yang dikatakan Velasko (2016), bahwa strategi advokasi yang juga dapat dilakukan melalui membangun jejaring dan koalisi, penelitian dan analisa kebijakan, pendidikan politik dan peningkatan kesadaran. Hal ini 
merupakan strategi didalam mencapai kesepakatan. Terdapat tiga lini advokasi yang perlu diperhatikan agar tujuan advokasi dapat berjalan dengan lancar, (Pujileksono, 2016).

Tiga lini advokasi yang dimaksud, yaitu: 1) Lini Legislatif/isi (countent of law), yaitu penjabaran tertulis dari suatu kebijakan yang tertuang dalam bentuk perundang-undangan, peraturan- peraturan dan keputusan pemerintah. Lini ini bertujuan untuk mendorong terciptanya payung hukum; 2) Lini eksekutif/ struktur/tata laksana (structure of law), yaitu perangkat pelaksana dari isi hukum yang berlaku. Semua perangkat kelembagaan dan pelaksana dari sistem hukum yang berlaku. Dalam pengertian ini tercakup lembaga-lembaga hukum (pengadilan, penjara, birokrasi, partai politikdan lain-lain) dan aparat pelaksananya (hakim, jasa, pengacara, polisi, tentara, pejabat pemerintah, anggota parlemen); 3) Lini mobilisasi sosial masyarakat/budaya hukum (culture of law), yaitu persepsi, pemahaman, sikap penerimaan kedua fokus diatas. Lini ini bertujuan untuk mengubah perilaku masyarakat agar sesuai dengan produk hukum. Dalam pengertian ini juga mencakup bentuk-bentuk tanggapan (reaksi, respon) masyarakat luas terhadap pelaksanaan isi dan tata laksana hukum tersebut.

Dari ketiga lini advokasi tersebut, merupakan satu kesatuan dalam melakukan advokasi. Satu lini dengan lini yang lain harus saling bersangkutan, memiliki pandangan dan pendapat yang sama untuk mecapai tujuan advokasi salah satunya tujuan untuk Undang-undang PRT tersebut sebagai payung hukum bagi ART yang mengalami tindak kekerasan serta penelantaran hakhaknya sebagai ART. Lini yang pertama menjelaskan bahwa lini legislatif ini mendorong untuk terbentuknya Undang-undang. Dalam kasus ini Undangundang PRT yang masih menggantung di Badan Legislatif DPR RI. Lini kedua adalah lini eksekutif yang memang sebagai isi dari tata laksana yang dapat mendukung terbentuknya Undang-undang baru sesuai dengan tugas yang akan mereka emban dalam penegakan hukum.

Advokasi yang dilakukan LBH APIK tidak hanya melakukan advokasi dalam perubahan hukum maupun dalam bentuk undang-undang yang baru, melainkan ada advokasi yang berbentu ke dalam penanganan kasus. Sebuah cara memahami advokasi sosial dalam praktik kontenporer adalah untuk mempertimbangkan sejumlah kerangka teoritis yang telah dikembangkan dalam praktik advokasi generik. Terdapat dua model untuk mengidentifikasi 
Advokasi Hak-hak Perempuan Asisten Rumah Tangga oleh Lembaga Bantuan Hukum Asosiasi Perempuan untuk Keadilan (LBH APIK) Jakarta

- Ayu Sopia Yudistika

dua unsur advokasi Pujileksono (2016).

Pertama, Kasus atau advokasi berbasis masalah, salah satu upaya untuk memberikan layanan dalam bantuan hukum, memang dibutuhkan lembaga yang memberikan pelayanan untuk membantu maupun melindungi korban dari tindak kekerasan maupun terkait dengan hak-hak yang seharusnya diperoleh, khususnya para kaum perempuan yang sering dianggap sebelah mata atau dianggap lemah. LBH APIK Jakarta merupakan lembaga yang memberikan layanan hukum bagi perempuan korban kekerasan maupun para pekerja. perempuan yang ingin memperjuangkan hak-haknya.

Dari penjelasan diatas LBH APIK Jakarta merupkan lembaga khusus yang berdiri dengan memberikan bantuan hukum kepada para kaum perempuan maupun anak. LBH APIK menangani beberapa kasus yang berkaitan dengan hak-hak perempuan dan anak serta menangani kasus-kasus kekerasan yang dialami perempuan dan juga hak-hak pekerja perempuan.

Dari hasil wawancara bahwa kategori ART yang sering ditangani yaitu ART yang mengalami kekerasan dalam bekerja, tidak mendapatkan upah, mengalami kekerasan seksual, mengalami kekerasan fisik, mendapatkan ancaman dan terjadi intimidasi yang membuat ART sulit untuk bertahan dalam pekerjaannya serta takut untuk berhenti dari pekerjaannya. Hal ini di karenakan perlakuan majikan yang terkadang semena-mena dan tidak memikirkan martabat seseorang sebagai manusia.

Selain itu, salah satu cara yang dilakukan LBH APIK Jakarta dalam melakukan identifikasi masalah korban yang mengalami tindak kekerasan atau penelantaran hak-hak pekerja. Salah satu caranya (Pujileksono, 2016), yaitu sebagai berikut:

"Yang pasti korban pertama datang, melaporkan kejadiannya bahwa dia mengalami kekerasan, kalau misalnya pas datang babak belur, berdarahdarah, ya kita tolongin dulu mba, tapi kalau datang dengan kondisi biasa aja ya kita liat dia mengalami apa nih, kekerasan apa, kalau kekerasannya ada unsur pidana ya kita laporkan proses hukum ke kepolisian. Tapi, kalau memang dia hubungannya ada pelanggaran pekerjaan dan hubungan pekerja dengan majikan ya kita bisa lakukan mediasi dulu awaalnya. Kita panggil si pekerja dengan majikannya. Kita jelaskan bahwa ini ada masalah administrasi yang belum diselesaikan."

Dalam melakukan identifikasi masalah LBH APIK Jakarta secara sigap memberikan pertolongan terhadap korban yang mengalami kekerasan 
dari majikannya. Berdasarkan pernyataan Ibu Zuma diatas, bahwa hal ini bisa terjadi oleh siapapun dan kapan pun. Termasuk dalam kasus ini seorang anggota Dewan, orang yang terpandang, orang yang mengerti dengan hukum, orang yang berpendidikan tinggi dan seharusnya bekerja untuk kesejahteraan rakyatnya. Kekerasan terhadap kaum perempuan terutama pekerja yang memang dalam posisi kerja masih dikategorikan sebagai pekerja informal atau pekerja domestik yang sering kali dianggap tidak penting serta seringkali termarjinalkan. Sering kali kebanyakan orang menganggap pekerjaan seperti ART dipandang sebelah mata, mereka dianggap hanya sebagai pembantu dalam rumah tangga. Terutama ART perempuan yang memang rentan sekali mengalami tindak kekerasan, baik kekerasan seksual, kekerasan fisik maupun kekerasan psikis.

Kasus-kasus yang ditangani oleh LBH APIK membutuhkan pemulihan terhadap psikisnya. Maka dari itu, LBH APIK harus bisa meyakinkan korban dalam kondisi trauma ataupun ketakutan memang sedikit sulit, butuh kesabar dan juga sikap meyakinkan kepada korban agar korban dapat percaya bahwa korban dalam keadaan aman tanpa adanya ancaman dari siapaun. Upaya yang dilakukan dalam meyakinkan korban, Staf LBH APIK Jakarta mengantarkan korban ke kantor polisi untuk menjelaskan semua yang terjadi terhadapnya. Selain itu dalam upaya melindungi korban, LBH APIK membawa korban ke LPSK sebagai Lembaga yang melindungi saksi dan korban untuk memberikan rasa aman terhadap korban. Sehingga tidak ada lagi tindakan yang semenamena atau mengancam keselamatan korban.

Berkoalisi atau bekerjasama dengan pihak lain merupakan bentuk kekuatan untuk mencapai suatu tujuan dari advokasi itu sendiri. Dengan melakukan koalisi atau kerjasama dengan pihak atau lembaga lain mempermudah untuk melakukan advokasi.

Hambatan dalam proses advokasi penanganan kasus yakni rata-rata seorang ART tersebut tinggal di luar daerah. Sehingga dalam proses advokasi tersebut sedikit mengalami kendala seperti halnya ART memilih tidak melanjutkan kegiatan advokasi ini karena mereka beranggapan bahwa hal yang terpenting dalam diri mereka untuk bebas dari pekerjaan maupun majikannya sudah tercapai. Maka dari itu proses advokasi ini biasanya hanya selesai di tahap mediasi saja dengan berbagai macam bentuk ganti rugi dan sebagainya. Sebagaimana diketahui bahwa untuk memunculkan efek jera kepada majikan yang memperlakuakan ART semena-mena seharunya proses ini sampai keranah 


\section{Advokasi Hak-hak Perempuan Asisten Rumah Tangga oleh Lembaga Bantuan Hukum Asosiasi Perempuan untuk Keadilan (LBH APIK) Jakarta}

- Ayu Sopia Yudistika

hukum.

Kedua, Sistemik atau menyebabkan advokasi, beberapa kasus yang dihadapi oleh LBH APIK yakni berkaitan dengan perlindungan perempuan dan anak. Banyaknya tindak kekerasan maupun perlakuan diskriminasi umumnya terhadap perempuan maka membuat LBH APIK melakuakan advokasi legislasi dalam upaya mewujudkan masyarakat yang adil dan demokrasi, serta menciptakan kondisi yang setara antara laki-laki dan perempuan dalam segala aspek kehidupan, baik politik, ekonomi, sosial dan budaya. Tujuan ini hendak dicapai dengan mewujudkan sistem hukum yang berperspektif perempuan yaitu sistem hukum yang adil dipandang dari pola hubungan kekuasaan dalam masyarakat. Meskipun penanganan kasus harus sesuai dengan perundang-undangan memang tidak semudah yang dibayangkan dan memang membutuhkan banyak waktu.

Pihak LBH APIK sedang mengusulkan Rancangan Undang-Undang agar bisa disahkan menjadi Undang-undang untuk melindungi perempuan ART. Sebab LBH APIK berupaya melindungi kaum perempuan untuk memperoleh keadilan dari UU tersebut.

\section{Advokasi LBH APIK terhadap Hak-hak Perempuan}

ART dalam posisi kerja masih dikategorikan sebagai pekerja informal atau pekerja domestik yang sering kali dianggap tidak penting serta seringkali termarjinalkan. Kebanyakan orang menganggap pekerjaan seperti itu (ART) dipandang sebelah mata, terutama ART perempuan yang memang rentan sekali mengalami tindak kekerasan, intimidasi, diskriminasi dan juga penelantaran hak-haknya sebagai pekerja.

Sehingga upaya yang dilakukan dalam melindungi ART sebagai pekerja maka dibutuhkan sebuah Undang-undang sebagai regulasi. Undang- Undang PRT merupakan bentuk regulasi yang dibutuhkan dalam melindungi dan mempertahankan hak-haknya dari tindak kekerasan maupun diskriminasi disaat bekerja. Tetapi, untuk saat ini undang-undang tersebut masih terhambat di tingkat DPR. Sehingga payung hukum yang khusus melindungi ART dari tindak kekerasan dan penelantaran hak-haknya belum bisa dipergunakan dalam melindungi ART.

Dalam hal ini, untuk melindungi ART dari tindak kekerasan, intimidasi dan penelantaran hak-haknya maka diperlukan suatu Lembaga Bantuan Hukum 
yang dapat memberikan pendampingan terhadap perempuan asisten rumah tangga salah satunya LBH APIK Jakarta yang memberikan bantuan hukum khususnya bagi perempuan Indonesia untuk mendapatkan perlindungan dalam bekerja dan juga bentuk keadilan.

Maka, salah satu regulasi yang digunakan oleh LBH APIK Jakarta sebagai regulasi terkait dengan perlindungan bagi perempuan ART yaitu UndangUndang KDRT.

Maka dari itu, Undang-undang KDRT dapat digunakan sebagai regulasi dalam melindungi ART dari tindak kekerasan maupun penelantarah hak-hak. Karena, pada dasarnya kekerasan yang dialami di lingkungan keluarga dapat terjadi kepada seorang suami terhadap istri, istri terhadap suami, penelataran anak dan juga hubungan majikan dengan ART nya baik itu bentuk kekerasan maupun penelantaran hak-hak seorang ART. Selain itu upaya yang dilakuakan LBH APIK Jakarta dalam melindungi perempuan asisten rumah tangga yaitu LBH APIK dan JALA PRT yang bekerjasama untuk segera terbentuknya undangundang PRT. Upaya ini dilakukan agar masyarakat khususnya perempuan asisten rumah tangga memahami apa saja yang menjadi hak dan kewajibannya sebagai perempuan pekerja. Serta hal ini pun membantu perempuan asisten rumah tangga agar terlepas dari bentuk kekerasan dan ketidakadilan selama bekerja. Terlepas dari itu, adanya LBH APIK Jakarta sebagai lembaga bantuan hukum khususnya bagi perempuan, hal ini mempermudah perempuan asisten rumah tangga untuk melaporkan semua masalah yang terjadi, sehingga mempermudah para perempuan asisten rumah tangga untuk mendapatkan keadilan.

Selain dari landasan hukum nasional maupun internasional, landasan hukum agama terutama agama Islam yang menjadi mayoritas masyarakat di Indonesia, dapat menjadi dasar dalam bagi LBH APIK Jakarta dalam menolong orang lain. Karena dalam agama diajarkan bahwa sesama manusia diharuskan untuk saling tolong menolong terutama kepada mereka yang memiliki kelemahan baik secara fisik, batin, material ataupun kekuasaan.

Berdasarkan perspektif pekerjaan sosial, kegiatan advokasi juga menjadi bagian dari kegiatan dari pekerja sosial. Hal ini dijelaskan pada Undangundang Nomor 23 Tahun 2002 tentang Perlindungan Anak Pasal 1 ayat (14) yang dimaksud Pendamping adalah pekerja sosial yang mepunyai kompetensi profesional dalam bidangnya. Undang-undang Nomor 11 tahun 2012 tentang Sistem Peradilan Pidana Anak pada Pasal 1 ayat (14) yang dimaksud Pekerja 


\section{Advokasi Hak-hak Perempuan Asisten Rumah Tangga oleh Lembaga Bantuan Hukum Asosiasi Perempuan untuk Keadilan (LBH APIK) Jakarta}

- Ayu Sopia Yudistika

Sosial Profesional adalah seseorangyang bekerja, baik di Lembaga pemerintahan maupun swasta, yang memiliki kompetensi dan profesi pekerja sosial serta kepedulian dalam pekerjaan sosial yang diperoleh melalui pendidikan, pelatihan dan/atau pengalaman praktik pekerjaan sosial untuk melaksanakan tugas pelayanan dan penanganan masalah sosial anak.

Adapun aktivitas pekerja sosial yang bersinggungan dengan bantuan hukum memiliki kaitan dengan perlindungan sosial. Hal ini diatur dalam UndangUndang Republik Indonesia Nomor 11 Tahun 2009 tentang Kesejahteraan sosial. Perlindungan sosial dimaksud untuk mencegah dan menangani risiko dari guncangan dan kerentanan sosial seseorang, keluarga, kelompok dan/ atau masyarakat agar kelangsungan hidupnya dapat dipenuhi sesuai dengan kebutuhan dasar minimal. Perlindungan sosial yang diamanatkanoleh UndangUndang Kesejahteraan Sosial ini dilaksanakan melalui pasal 14 ayat (2): (a) Bantuan Sosial, (b) Advokasi Sosial, (c) Bantuan Hukum, (Pujileksono, 2016).

\section{Bantuan Sosial}

Bantuan sosial yang dimaksudkan agar seseorang, keluarga, kelompok dan/atau masyarakat yang mengalami guncangan dan kerentanan sosial dapat tetap hidup secara wajar. Bantuan sosial diberikan dalam bentuk bantuan langsung, penyediaan aksesibilitas dan penguatan kelembagaan.

\section{Advokasi Sosial}

Advokasi sosial dimaksud untuk melindungi dan membela seseorang, keluarga, kelompok dan/atau mayarakat yang dilanggar haknya. Advokasi ini diberikan dalam bentuk penyadaran hak kewajiban, pembelaan dan pemenuhan hak. Undang-Undang sosial dapat digunakan oleh pekerja profesional sebagai alat untuk advokasi sosial, pemberdayaan untuk memastikan dasar hak asasi manusia, martabat dan lingkungan yang kondusif.

\section{Bantuan Hukum}

Bantuan hukum menurut UU Kesejahteraan Sosial diselenggarakan untuk mewakili kepentingan warga negara yang menghadapi masalah hukum dalam pembelaan atau hak, baik di dalam maupun di luar pengadilan. Bantuan hukum diberikan dalam bentuk pembelaan dan konsultasi hukum.

Maka dari itu, berdasarkan pengertian Profesi Pekerja Sosial dibeberapa undang-undang yang telah disebutkan di atas, menunjukan bahwa pekerja 
sosial telah diakui keberadaannya oleh undang-undang sebagai sebuah profesi yang menjalankan tugas dibidang kesejahteraan sosial termasuk dalam melakukan kegiatan advokasi atau pendampingan terhadap klien. Oleh karena itu, seharusnya pekerja sosial juga bisa mendapatkan tempat dalam melakukan advokasi terhadap permaslahan-permaslahan perempuan Asisten Rumah Tangga terkait dengan hak-hak asisten rumah tangga. Salah satunya dengan cara melakukan pendampingan ataupun memberikan penyadaran terkait dengan hak dan kewajiban perempuan asisten rumah tangga, dan melakukan pembelaan dan pemenuhan hak-hak perempuan asisten rumah tangga.

Adapun dalam hal ini, LBH APIK Jakarta sebagai lembaga yang melakukan advokasi terhadap perempuan Asisten Rumah Tangga membuka diri untuk bekerjasama dengan berbagai pihak ataupun dengan berbagai profesi sesuai dengan ranah pekerjaanya masing-masing.

Dari penjelasan diatas bahwa, LBH APIK Jakarta membuka diri untuk bekerjasama atau bermitra dengan berbagai profesi terutama profesi pekerja sosial yang memang sebagai profesi penolong bagi masyarakat yang tidak mampu untuk mendapatkan haknya. Adapun di dalam pelaksanaan advokasi pekerja sosial dapat melakukan pendampingan, penyuluhan dan lain sebagainya sesuai dengan ranah pekerja sosial terutama untuk menjadi staf di LBH APIK Jakarta pekerja sosial bisa masuk di dalam pelayanan hukum dan juga perubahan hukum sesuai dengan jobdesk nya masing-masing.

\section{Kesimpulan}

Berdasarkan penelitian yang telah dilakukandi Lembaga Bantuan Hukum Asosiasi Perempuan Indonesia untuk Keadilan (LBH APIK) Jakarta, terdapat dua kesimpulan, yakni pertama terkati dengan regulasi dan kedua advokasi.

Pertama, Regulasi terkait dengan perempuan Asisten Rumah Tangga Salah satu bentuk regulasi di Indonesia yaitu perundang-undangan yang menjadi dasar hukum bagi masyarakat Indonesia. Dalam hal ini, sebagai bentuk perlindungan terhadap ART maka diperlukan sebuah Undang-Undang khusus terkait dengan ART yaitu Undang-Undang PRT yang sampai saat ini masih menggatung di DPR. Selama Undang-Undang PRT belum disahkan, maka dapat menggunakan beberapa regulasi dalam melakukan bantuan hukum khususnya pemenuhan hak-hak perempuan asisten rumah tangga. Berikut regulasi yang dapat digunakan: a) Undang-Undang Nasional: Undang-Undang Dasar 1945, 


\section{Advokasi Hak-hak Perempuan Asisten Rumah Tangga oleh Lembaga Bantuan Hukum Asosiasi Perempuan untuk Keadilan (LBH APIK) Jakarta}

- Ayu Sopia Yudistika

Undang-Undang Hak Asasi Manusia, Undang-Undang Anti Kekerasan Dalam Rumah Tangga (KDRT), Undang-Undang Ketenagakerjaan, Peraturan Menteri dan Peraturan Daerah; dan b) Undang-Undang Internasional: Konvensi Internasional Labour Office (ILO), Deklarasi Universal Hak Asasi Manusia, Konvensi Internasional tentang Hak- hak sipil dan politik dan Konvensi Internasional tentang Dampak Ekonomi, Sosial dan Budaya.

Dalam hal ini, salah satu regulasi yang digunakan oleh LBH APIK Jakarta dalam melakukan advokasi terhadap perempuan ART yaitu menggunakan Undang-Undang KDRT. Undang-undang tersebut dianggap tepat untuk diterapkan dalam penanganan kasus ART terutama terkait dengan hak-hak dan perlindungan ART selama bekerja.

Adapun perspektif pekerjaan sosial sesuai dengan Undang-undang Kesejahteraan Sosial dan Undang-undang PKDRT yang memang memberikan tempat bagi profesi pekerja sosial untuk melakukan advokasi terhadap hak-hak perempuan Asisten Rumah Tangga.

Kedua, Advokasi Hak-hak perempuan Asisten Rumah Tangga oleh LBH APIK Jakarta. Secara umum, LBH APIK Jakarta memiliki latar belakang kepedulian bersama tentang perlunya pemberian pelayanan dan bantuan hukum kepada perempuan dengan sikap dan perspektif yang lebih berpihak pada perempuan. Maka LBH APIK Jakarta menjadi Lembaga Bantuan Hukum untuk perempuan pertama di Indonesia. Dalam hal ini, advokasi yang dilakukan LBH APIK Jakarta yaitu dalam bentuk penanganan kasus dan sistemik atau bentuk perubahan kebijakan serta advokasi suatu bentuk undang-undang baru khusunya yang berspektif gender (perempuan).

Penanganan Kasus: Memberikan bantuan hukum secara cuma-cuma bagi msyarakat kurang mampu, menangani kasus kekerasan dalam rumah tangga, menangani kasus kekerasan seksual tehadap perempuan dan menangani kasus yang dialami seorang Asisten Rumah Tangga terkait dengan perlindungan hak-haknya, terbebas dari ancaman, terbebas dari tindakan kekerasan intimidasi serta pelecehan seksual dalam bekerja.

Sistemik: Melakukan advokasi legilasi, seperti Undang-Undnag PKDRT, Undang-Undang Traffiking, KUHP, Undang-Undang Kesehatan, Amandemen perkawinan serta merancang Undang-Undang KKG, Undang-Undang PRT dan Undang-Undang PKS. 


\section{Daftar Pustaka}

Herdiansyah, H. (2012). Metode Penelitian Kualitatif Ilmu-Ilmu Sosial. Jakarta: Salemba Humanika.

Hidayati, M. N. (2016). Upaya Perlindungan Pekerja Rumah Tangga sebagai Kelompok Masyarakat yang Termarjinalkan di Indonesia. Jurnal Al-Ahzar Indoensia, 1.

Indriati, M. F. (2007). Ilmu Perundang-undangan: Jenis, Fungsi dan Materi Muatan. Yogyakarta: Kanisius.

Maelong, L. J. (2007). Metode Penelitian Kualitatif. Bandung: PT Remaja Rosdakarya.

Pujileksono, S. (2016). Perundang-undangan Sosial dan Pekerjaan Sosial. Malang: Setara Press.

Sugiyono. (2010). Metode Penelitian Kuantitatif dan Kualitatif. Bandung: Alfabeta.

Sunyoto, B. (2013). Metodologi Penelitian Akuntansi. Bandung: Refika Aditama. Turatmiyah, S., \& Y, A. (2013). Pengakuan Hak-hak Perempuan sebagai Pekerja Rumah Tangga sebagai Bentuk Perlindungan Hukum Positif Indonesia. 13. Wiludjeng, H. (2005). Dampak Pembekuan Peran Gender Terhadap Perempuan Kelas Bawah di Jakarta. Jakarta: LBHAPIK.

Zuriah, N. (2007). Metodologi Penelitian Sosial dan Pendidiakan: Teori Aplikasi. Jakarta: PT Bumi Aksara 